\title{
HAMBATAN DALAM PELAKSANAAN PEMBELAJARAN MATA KULIAH TEMBANG DI JURUSAN PENDIDIKAN SENI TARI UNY
}

\author{
EMG. Lestantun M.K. \\ Fakultas Bahasa dan Seni, Universitas Negeri Yogyakarta \\ E-mail: lestantun@uny.ac.id
}

\begin{abstract}
Abstrak
Penelitian ini bertujuan untuk mengetahui: 1) Pelaksanaan pembelajaran mata kuliah tembang di jurusan pendidikan seni tari UNY. 2) Mengetahui hambatan dalam proses pembelajaran mata kuliah tembang di jurusan pendidikan seni tari UNY. Jenis penelitian ini adalah deskriptif kualitatif. Penelitian ini dilakukan pada saat mata kuliah berlangsung dengan metode observasi, wawancara, dan dokumentasi. Hasil dari penelitian yang dilakukan pada 10 mahasiswa di kelas $\mathrm{N}$ semester 4 pada mata kuliah tembang adalah: Faktor-Faktor Penghambat Mata Kuliah Tembang di jurusan pendidikan seni tari UNY pada mahasiswa luar jawa, sering mengalami kesulitan pada logat, pengucapan. Perbedaan bahasa dan cara pengucapan antar daerah yang berbeda, notasi yang menggunakan bahasa jawa, pengalaman awal pada tembang.
\end{abstract}

Kata Kunci: faktor penghambat, pembelajaran, tembang

\section{OBSTACLES IN TEACHING LEARNING PROCESS OF TEMBANG COURSE IN THE DEPARTMENT OF DANCE EDUCATION UNY}

\begin{abstract}
This study aims to determine: 1) Implementation of learning courses in the Department of Dance Education UNY. 2) obstacles in the teaching learning process of Tembang course in the Department of Dance Education UNY. The type of this research is descriptive qualitative. This research is done at the time of the course with observation method, interview, and documentation. The results of the research conducted on 10 students in grade 4th semester are: accent, pronunciation, the language in tembang, and the first experience in the course.
\end{abstract}

Keywords: obstacles in teaching learning, Tembang course

\section{PENDAHULUAN}

Pendidikan adalah usaha sadar dan terencana untuk mewujudkan suasana belajar dan proses pembelajaran untuk peserta didik secara aktif mengembangkan potensi dirinya. Dalam proses pembelajaran tersebut, dalam akademik maupun non akademik terjadi transfer ilmu antar pendidik dengan peserta didik,sharing ilmu pengetahuan dari peserta didik dengan peserta didik, yang bersifat lisan maupun tertulis, agar peserta didik dapat menerima banyak pengalaman belajar dan dapat mengembangkan pikirannya. Pada saat peserta didik menerima suatu pendidikan secara akademik maupun nonakademik, mereka dapat belajar mengenai nilai, moral, pendidikan karakter.

Sebuah pendidikan tidaklah lepas dari proses pembelajaran mengenai berbagai macam materi secara tertulis maupun praktik. Materi pelajaran sangatlah beragam, tak terkecuali kebudayaan. Konteks Kebudayaan mempunyai ruang lingkup yang beragam seperti ini yaitu, tari, lagu, bahasa, ras, rumah adat, dan sebagainya. Indonesia memiliki banyak aneka ragam budaya yang berbeda satu 
sama lain antar pulau, suku,dan daerah. Oleh sebab itu, terkadang pembelajaran mengenai budaya sering kali menemui penghambat, salah satunya tembang. Peserta didik yang tinggal di luar Jawa, sering kali mengalami kendala pada saat bernyanyi dan lafal (logat dan bahasa).

Melalui penelitian ini, kami berharap agar faktor-faktor penghambat pada mata kuliah tembang di pendidikan seni tari UNY, dapat diatasi dan pendidikan seni tari semakin berkualitas dalam mata kuliah salah satunya pada mata kuliah tembang.

\section{METODE}

1. Subyek Penelitian

Subyek pada penelitian ini adalah mahasiswa semester 4 kelas $\mathrm{N}$ di jurusan pendidikan seni tari UNY yang berjumlah 10 orang.

\section{Pendekatan Penelitian}

Berdasarkan pokok masalah yang dikaji, penelitian yang berjudul Faktor-Faktor Penghambat Pembelajaran Mata Kuliah Tembang di Jurusan Pendidikan Seni Tari UNY. Pendekatan yang digunakan oleh peneliti adalah pendekatan kualitatif dengan metode deskriptif kualitatif.

\section{Tempat Penelitian}

Tempat penelitian dengan judul FaktorFaktor Pembelajaran Mata Kuliah Tembang di Jurusan Pendidikan Seni Tari UNY, bertempat di Ruang Laboratorium Karawitan lantai 2 Universitas Negeri Yogyakarta.

\section{Data Penelitian}

Data pada penelitian ini bersifat deskriptif. Data penelitian kualitatif itu menggunakan kata-kata, kalimat, teks, dan foto.

\section{Teknik Pengumpulan Data}

Teknik pengumpulan data merupakan langkah yang paling strategis dalam penelitian, karena tujuan penelitian adalah mendapatkan data. Pengumpulan data dapat dilakukan dalam berbagai setting, berbagai sumber dan berbagai cara (Sugiyono, 2014: 62). Dalam penelitian kualitatif ini, teknik pengumpulan data yang digunakan adalah:

\section{a. Observasi}

Observasi atau yang disebut dengan pengamatan adalah alat untuk memotret seberapa jauh efek tindakan telah mencapai sasaran (Suyadi, 2010: 63). Hal-hal yang perlu untuk diamati dalam proses observasi ini adalah cara dosen dalam memberi perkuliahan, cara kerja mahasiswa dalam perkuliahan, dan cara dosen dalam menangani faktor penghambat kesulitan mata kuliah tembang.

b. Wawancara Mendalam

Wawancara ini dilakukan kepada beberapa mahasiswa kelas $\mathrm{N}$ yang mengalami kesulitan pada mata kuliah tembang secara acak.

c. Dokumentasi

Pendokumentasian diambil pada saat mahasiswa kelas $\mathrm{N}$ ujian tembang sebagai pendukung penelitian ini.

\section{HASIL DAN PEMBAHASAN}

a. Proses Pembelajaran Tembang di Jurusan Pendidikan Seni Tari UNY

\subsection{Prasiklus}

Penelitian yang berjudul faktor-faktor penghambat pembelajaran mata kuliah tembang di jurusan pendidikan seni tari UNY diawali dengan mengurus perizinan dengan dekan dan meminta surat. Setelah memperoleh izin, peneliti melakukan observasi untuk mengidentifikasi masalah dengan mengamati kegiatan perkuliahan. Peneliti juga melakukan wawancara kepada salah satu mahasiswa luar Jawa dari kelas $\mathrm{N}$ jurusan pendidikan seni tari. Tujuan wawancara ini adalah untuk mengumpulkan informasi terkait kegiatan perkuliahan yang terjadi.

\subsection{Proses Pembelajaran Tembang}

Proses Pembelajaran tembang di kelas $\mathrm{N}$ semester 4 di jurusan pendidikan seni tari berlangsung pada hari senin dan kamis pukul 09.00 WIB. 


\subsubsection{Pertemuan Pertama}

Pada pertemuan pertama dilakukan dengan salam, dilanjutkan dengan berdoa dan mahasiswa satu persatu melakukan presensi. Kemudian dosen apersepsi, dengan memberikan pengantar dan melakukan tanya jawab mengenai pengetahuan tentang mahasiswa mengenai materi yang berhubungan dengan mata kuliah tembang. Setelah itu,dosen menjelaskan tujuan perkuliahan yang akan dilakukan serta menjelaskan kegiatan apa saja yang akan dilakukan oleh mahasiswa dalam mata kuliah tembang. Mahasiswa mencatat materi dan tujuan dari mata kuliah tembang.

Kegiatan inti dimulai dosen membacakan silabus, menjelaskan secara singkat tentang pengertian tembang, jenis tembang yang akan dipelajari selama mata kuliah berlangsung, dan contoh tembang dalam tarian, setelah itu dilanjutkan dengan dosen memberikan materi serta pengetahuan tentang tembang.

\subsubsection{Pertemuan Kedua}

Kegiatan dimulai dengan salam, dilanjutkan dengan berdoa dan mahasiswa satu persatu melakukan presensi. Kemudian dosen apersepsi mengenai materi sebelumnya. Beberapa mahasiswa aktif untuk diajak bertanya jawab pada saat apersepsi,mereka mengemukakan materi yang sudah dipelajari lampau hari. Namun sebagian mahasiswa belum terlihat aktif.

Kegiatan inti pada pertemuan kedua ini dimulai dengan dosen mengingatkan kembali mengenai materi teori yang sudah diberikan.

Pada pertemuan ini, dosen memberikan motivasi dan penjelasan kepada mahasiswa melalui 4 pilar UNESCO :

$>$ Learning to know (belajar mengetahui)

$>$ Learning to do (belajar melakukan sesuatu)

$>$ Learning to be (belajar menjadi sesuatu)
Learning to live together (belajar hidup bersama)

\subsubsection{Pertemuan Ketiga}

Pada pertemuan ketiga dilakukan dengan salam, dilanjutkan dengan berdoa dan mahasiswa satu persatu melakukan presensi. Dilanjutkan dengan memulai mata kuliah tembang. Dosen memberikan kesempatan kepada mahasiswa untuk menyanyikan bersama Rambangan Durma Laras Slendro Pathet Sanga secara bersama sama.

Selanjutnya mahasiswa diberi kesempatan oleh dosen untuk mencoba satu persatu menyanyikan Rambangan Durma Laras Slendro dengan arahan dosen.

Pada akhir mata kuliah diakhiri dengan salam dan doa.

\subsubsection{Pertemuan Keempat}

Pertemuan ke empat diawali dengan salam dan doa. Dilanjutkan dengan kegiatan inti yaitu mengulang untuk menyanyikan tembang Rambangan Durma Laras Slendro dengan arahan dosen. Pada pertemuan kali ini, mahasiswa diajak menyanyi dengan tinting yang menggunakan alat bantu gender dengan tujuan mempermudah mahasiswa mencapai nada.

Pada akhir pertemuan ke empat, dosen menginformasikan mengenai evaluasi I mata kuliah tembang pada pertemuan mendatang.

Ditutup dengan salam dan doa penutup.

\subsubsection{Pertemuan Kelima}

Pertemuan kelima dimulai dengan salam dan doa. Dilanjutkan dengan evaluasi I, dengan kegiatan mahasiswa satu persatu maju ke depan untuk menyanyikan tembang Rambangan Durma Laras Slendro.

Dari evaluasi I yang telah dilakukan, berikut adalah daftar nilai mata kuliah tembang kelas N: 
Tabel 2. Nilai Evaluasi I Mahasiswa Kelas N mata kuliah Tembang

\begin{tabular}{clcc}
\hline No & \multicolumn{1}{c}{ Nama } & NIM & Nilai \\
\hline 1. & Della Ambarsari & 15209244006 & 70 \\
2. & Yudhani Prasetya & 15209244007 & 79 \\
& Putri & & \\
3. & Indah Sukma & 15209244008 & 78 \\
& Purwaningtyas & & \\
4. & Ike Nurafifah Jatmi & 15209244009 & 75 \\
5. & Kurniawati & 15209244010 & 76 \\
& Widyaningrum & & \\
6. & Pina Handayani & 15209244012 & 78 \\
7. & Tatas Pradhika & 15209244013 & 75 \\
& Wahyu Catur & & \\
8. & Indah Sawitri & 15209244016 & 76 \\
9. & Ikshan Sadiyah & 15209244017 & 79 \\
10. & Asri Maulinda & 15209244018 & 70 \\
\hline
\end{tabular}

\subsubsection{Pertemuan Keenam}

Pertemuan ke enam dimulai dengan salam dan doa. Selanjutnya mahasiswa diberikan 2 tembang yaitu Rambangan Kinanthi Mangu dan Ladrang Asmaradana Kenyatinembe. Dosen memberikan contoh kepada mahasiswa dan memberikan rekaman tentang tembang tersebut. Pada pertemuan ini juga,dosen mengajak mahasiswa tinting dengan menggunakan gender. Hal ini bertujuan, untuk memudahkan mahasiswa mencapai nada tembang.

Dibawah ini adalah Tembang Rambangan Kinanthi Mangu dan Ladrang Asmaradana Kenyatinembe.

\subsubsection{Pertemuan Ketujuh, Delapan, Sembilan, dan Sepuluh}

Pada pertemuan ketujuh dilakukan dengan salam, dilanjutkan dengan berdoa dan mahasiswa satu persatu melakukan presensi. Dilanjutkan dengan memulai mata kuliah tembang. Dosen memberikan kesempatan kepada mahasiswa untuk menyanyikan bersama, tembang Rambangan Kinanthi Mangu dan Ladrang Asmaradana Kenyatinembe.

Selanjutnya mahasiswa diberi kesempatan oleh dosen untuk mencoba satu persatu menyanyikan Rambangan Kinanthi Mangu dan
Ladrang Asmaradana Kenyatinembe dengan arahan dosen.

Pada akhir mata kuliah diakhiri dengan salam dan doa.

Pada pertemuan kedelapan dilakukan dengan salam pembukaan, dilanjutkan dengan berdoa dan mahasiswa satu persatu melakukan presensi. Dilanjutkan dengan memulai mata kuliah tembang. Dosen memberikan kesempatan kepada mahasiswa untuk mendengarkan rekaman dari HP. Lalu diberikan kesempatan untuk menyanyikan bersama, tembang Rambangan Kinanthi Mangu dan Ladrang Asmaradana Kenyatinembe, serta mengulang ulang serta mencoba satu persatu dengan arahan dari dosen

Kegiatan inti yang dilakukan pada pertemuan kesembilan dan sepuluh adalah pendalaman mata kuliah tembang dengan materi Rambangan Kinanthi Mangu dan Ladrang Asmaradana Kenyatinembe.

Pada akhir perkuliahan, dosen memberikan informasi kepada mahasiswa bahwa evaluasi II akan dilaksakan pada pertemuan mendatang.

\subsubsection{Pertemuan Kesebelas dan Duabelas}

Kegiatan inti pada Pertemuan kesebelas adalah pendalaman serta dosen memberikan tugas kepada mahasiswa untuk melakukan apresiasi pentas seni wayang wong di jl. Parangtritis.

Pada pertemuan keduabelas, dosen melaksanakan evaluasi II. Teknis evaluasi II yang dilakukan dosen adalah mahasiswa satu persatu maju menuju podium dengan cara berjalan timpuh untuk evaluasi II mata kuliah tembang.

Pada saat evaluasi II berlangsung, mahasiswa putri menggunakan kebaya dan jarik berwiru, sedangkan mahasiswa putra menggunakan surjan beserta jarik berwiru.

Berikut adalah hasil dari evaluasi II mata kuliah tembang di kelas $\mathrm{N}$ semester 4 jurusan pendidikan seni tari UNY: 
Tabel 3. Daftar Nilai evaluasi II mata kuliah tembang di kelas $\mathrm{N}$ semester 4 jurusan pendidikan seni tari UNY (angkatan 2015)

\begin{tabular}{clcc}
\hline No & \multicolumn{1}{c}{ Nama } & NIM & Nilai \\
\hline 1. & Della Ambarsari & 15209244006 & 79 \\
2. & Yudhani Prasetya & 15209244007 & 89 \\
& Putri & & \\
3. & Indah Sukma & 15209244008 & 85 \\
& Purwaningtyas & & \\
4. & Ike Nurafifah Jatmi & 15209244009 & 80 \\
5. & Kurniawati & 15209244010 & 85 \\
& Widyaningrum & & \\
6. & Pina Handayani & 15209244012 & 80 \\
7. & Tatas Pradhika & 15209244013 & 78 \\
& Wahyu Catur & & \\
8. & Indah Sawitri & 15209244016 & 79 \\
9. & Ikshan Sadiyah & 15209244017 & 80 \\
10. & Asri Maulinda & 15209244018 & 78 \\
\hline
\end{tabular}

Tabel 4. Perbandingan Nilai antara evaluasi I dan evaluasi II mata kuliah tembang di jurusan pendidikan seni tari

\begin{tabular}{lcc}
\hline \multicolumn{1}{c}{ Keterangan } & Evaluasi I & Evaluasi II \\
\hline Nilai Tertinggi & 79 & 89 \\
Nilai Terendah & 70 & 78 \\
Rata-Rata & 75,6 & 81,3 \\
\hline
\end{tabular}

2) Faktor-Faktor Penghambat Mata Kuliah Tembang di jurusan pendidikan seni tari UNY

1.1 Faktor Penghambat Mata Kuliah Tembang Pada saat mata kuliah berlangsung, tidak jarang mahasiswa memiliki penghambat. Hal ini terjadi pada semua mahasiswa,yang berada di jawa atau di luar Jawa. Berdasarkan penelitian melalui pengamatan pada saat mata kuliah belangsung. Faktor penghambat yang mahasiswa kelas $\mathrm{N}$ alami pada mata kuliah tembang adalah:

a) Saat mata kuliah berlangsung, peneliti menemukan faktor penghambat yang dialami oleh beberapa mahasiswa kelas $\mathrm{N}$, terlebih pada mahasiswa luar Jawa. Mereka sering mengalami kesulitan pada logat, pengucapan. Perbedaan bahasa dan cara pengucapan antar daerah yang berbeda, mengakibatkan mahasiswa perlu belajar beberapa kali untuk mencerna kata-kata yang baru mereka temui. Misalnya pada saat mengucapkan "heh senggana, aja sira, tidha tidha", menurut logat jawa, kalimat tersebut dibaca dengan "heh senggono, ojo siro tido tido." Berdasarkan penelitian pada pertemuan pertama dan kedua, mahasiswa dari luar jawa membaca kalimat tersebut sesuai dengan tulisan serta mahasiswa membaca kalimat tersebut dengan terbatabata.

b) Notasi yang menggunakan bahasa Jawa

Pada saat pertemuan pertama, kedua, dan ketiga, beberapa mahasiswa kebingungan ketika diperhadapkan dengan notasi jawa. Ketika menyanyi tembang macapat yang telah disediakan oleh dosen, ketepatan nada yang dicapai belum mencapai hasil yang diharapkan (fals).

c) Kepercayaan diri mahasiswa dalam berperan aktif dalam mata kuliah tembang

Berdasarkan penelitian, pada pertemuan pertama dan kedua mata kuliah tembang, kepercayaan diri pada mahasiswa masih kurang. Hal ini terlihat dari beberapa mahasiswa pada saat bernyanyi, suara yang mereka keluarkan belum maksimal. Selain itu, mahasiswa terlihat malu-malu untuk bertanya mengenai kesulitan mereka mengenai mata kuliah tembang.

\subsection{Cara Mengatasi Faktor Penghambat Mata Kuliah Tembang}

Berdasarkan observasi yang dilakukan oleh peneliti di lapangan, dosen mengatasi penghambat yang ada di mata kuliah tembang, menggunakan beberapa cara:

a) Dengan menyetelkan rekaman yang berkaitan dengan mata kuliah tembang.

b) Apresiasi tembang ke luar.

c) Menyarankan mahasiswa untuk membawa contoh tembang yang dapat diambil dari google dan sebagainya.

d) Sharing antarteman.

e) Tinting atau menggunakan alat bantu gender untuk mengangkat nada yang akan dinyanyikan.

f) Mendampingi mahasiswa dalam menyanyi tembang. 
g) Memberikan motivasi kepada mahasiswa.

1.3 Target Capaian

1.3.1 Mahasiswa dapat mengetahui macam macam tembang

1.3.2 Mahasiswa dapat mempraktekkan tembang

1.3.3 Mahasiswa mendapatkan nilai yang cukup baik

Setelah dosen memberikan solusi,di bawah ini adalah nilai dari evaluasi yang dilakukan oleh peneliti:

\begin{tabular}{lcc}
\hline Keterangan & Evaluasi I & Evaluasi II \\
\hline Nilai Tertinggi & 79 & 89 \\
Nilai Terendah & 70 & 78 \\
Rata-Rata & 75,6 & 81,3 \\
\hline
\end{tabular}

\section{KESIMPULAN}

Proses pembelajaran tembang di kelas $\mathrm{N}$ semester 4 di jurusan pendidikan seni tari berlangsung pada hari senin dan kamis pukul 09.00 WIB. Setiap akan memulai pembelajaran, dilakukan dengan salam, berdoa dan melakukan presensi. Pada saat akhir dari mata kuliah pun diakhiri dengan doa penutup.

Pada pertemuan pertama, dosen apersepsi, dengan memberikan pengantar dan melakukan tanya jawab mengenai pengetahuan tentang mahasiswa mengenai materi yang berhubungan dengan mata kuliah tembang. Setelah itu,dosen menjelaskan tujuan perkuliahan yang akan dilakukan serta menjelaskan kegiatan apa saja yang akan dilakukan oleh mahasiswa dalam mata kuliah tembang. Mahasiswa mencatat materi dan tujuan dari mata kuliah tembang. Kegiatan inti dimulai dosen membacakan silabus, menjelaskan secara singkat tentang pengertian tembang, jenis tembang yang akan dipelajari selama mata kuliah berlangsung, dan contoh tembang dalam tarian.

Kegiatan pada pertemuan kedua ini dimulai dengan dosen mengingatkan kembali mengenai materi teori yang sudah diberikan serta dosen memberikan motivasi dan penjelasan kepada mahasiswa melalui 4 pilar UNESCO yaitu Learning to know, Learning to do, Learning to be, Learning to live together.
Pada pertemuan ketiga memulai mata kuliah tembang, dosen memberikan kesempatan kepada mahasiswa untuk menyanyikan bersama Rambangan Durma Laras Slendro Pathet Sanga secara bersama sama. Selanjutnya mahasiswa diberi kesempatan oleh dosen untuk mencoba satu persatu menyanyikan Rambangan Durma Laras Slendro dengan arahan dosen.

Pertemuan keempat dengan kegiatan inti yaitu mengulang untuk menyanyikan tembang Rambangan Durma Laras Slendro dengan arahan dosen. Pada pertemuan kali ini, mahasiswa diajak menyanyi dengan tinting yang menggunakan alat bantu gender dengan tujuan mempermudah mahasiswa mencapai nada.

Kegiatan inti pada pertemuan ke lima adalah evaluasi I, dengan kegiatan mahasiswa satu persatu maju ke depan untuk menyanyikan tembang Rambangan Durma Laras Slendro.

Pertemuan keenam, mahasiswa diberikan 2 tembang yaitu Rambangan Kinanthi Mangu dan Ladrang Asmaradana Kenyatinembe. Dosen memberikan contoh kepada mahasiswa dan memberikan rekaman tentang tembang tersebut. Pada pertemuan ini juga, dosen mengajak mahasiswa tinting dengan menggunakan gender.

Pada pertemuan ketujuh dosen memberikan kesempatan kepada mahasiswa untuk menyanyikan bersama, tembang Rambangan Kinanthi Mangu dan Ladrang Asmaradana Kenyatinembe. Selanjutnya mahasiswa diberi kesempatan oleh dosen untuk mencoba satu persatu menyanyikan Rambangan Kinanthi Mangu dan Ladrang Asmaradana Kenyatinembe dengan arahan dosen.

Pada pertemuan kedelapan memberikan kesempatan kepada mahasiswa untuk mendengarkan rekaman dari HP. Lalu diberikan kesempatan untuk menyanyikan bersama, tembang Rambangan Kinanthi Mangu dan Ladrang Asmaradana Kenyatinembe dan dilanjutkan dengan bernyanyi satu persatu.

Kegiatan inti yang dilakukan pada pertemuan kesembilan dan sepuluh adalah pendalaman mata kuliah tembang dengan 
materi Rambangan Kinanthi Mangu dan Ladrang Asmaradana Kenyatinembe.

Pada akhir perkuliahan, dosen memberikan informasi kepada mahasiswa bahwa evaluasi II akan dilaksakan pada pertemuan mendatang.

Kegiatan inti pada pertemuan kesebelas adalah pendalaman serta dosen memberikan tugas kepada mahasiswa untuk melakukan apresiasi pentas seni wayang wong di $\mathrm{jl}$. Parangtritis.

Pada pertemuan keduabelas, dosen melaksanakan evaluasi II yaitu mahasiswa satu persatu maju menuju podium dengan cara berjalan timpuh dan bernyanyi.

Pada saat evaluasi II berlangsung, mahasiswa putri menggunakan kebaya dan jarik berwiru, sedangkan mahasiswa putra menggunakan surjan beserta jarik berwiru.

Faktor Penghambat Mata Kuliah yaitu, ada mahasiswa luar Jawa, sering mengalami kesulitan pada logat, pengucapan, notasi yang menggunakan bahasa Jawa, pengalaman awal dalam mengenal tembang, kepercayaan diri mahasiswa dalam berperan aktif dalam mata kuliah tembang. Cara mengatasi faktor penghambat mata kuliah tembang yaitu dengan menyetelkan rekaman yang berkaitan dengan mata kuliah tembang, apresiasi tembang ke luar, menyarankan mahasiswa untuk membawa contoh tembang, tinting, sharing antarteman, dosen mendampingi mahasiswa dalam menyanyi tembang, dan memberi motivasi kepada mahasiswa. Target capaian pada mata kuliah ini adalah mahasiswa dapat mengetahui macam-macam tembang, mahasiswa dapat mempraktekkan tembang, mahasiswa mendapatkan nilai yang cukup baik, dan mahasiswa mengalami kenaikan nilai dan kemampuan.

\section{DAFTAR PUSTAKA}

\section{Buku :}

Sumaryadi, dkk. 2016. Pendidikan berbasis pendidikan karakter untuk mendukung revolusi mental, KUMPULAN ABSTRAK SEMINAR NASIONAL PENDIDIKAN SENITARI, Universitas Negeri Yogyakarta

Kartono, Kartini. 1996. Psikologi Umum/ Kartini Kartono. Bandung: Mandar Maju

Sudirman N, dkk. 2003. Ilmu Pendidikan. Bandung:Rosdakarya

IreneAstuti Dwiningrum, Siti.2016.Pendidikan Sosial Budaya. Yogyakarta:UNY Press

Warsito, Ronggo. 2002. Buku Pinter PEPAK $B A S A$ JAWA. Surabaya: Nusantara

\section{Internet :}

4 Pilar UNESCO :

http://dayanmaulana.blogspot.co.id/2010/06/ empat-pilar-pendidikan-menurut-unesco. html

Pengertian dan ciri-ciri pembelajaran :

http://eprints.uny.ac.id/8597/3/bab\%202\%20

$-\% 2008108249131 . p d f$

http://repository.unpas.ac.id/12994/4/ BAB\%20II.pdf

ht t p://arishiday at 89 . blog s pot. co.id/2014/01/pengertian-dan-ciri-ciripembelajaran_6305.html

http://rangkumanpustaka.blogspot. co.id/2017/04/15-ciri-ciri-belajarmenurut-ahli.html 


\section{Lampiran}

Gambar I. Ladrang Asmaradana Kenyatinembe

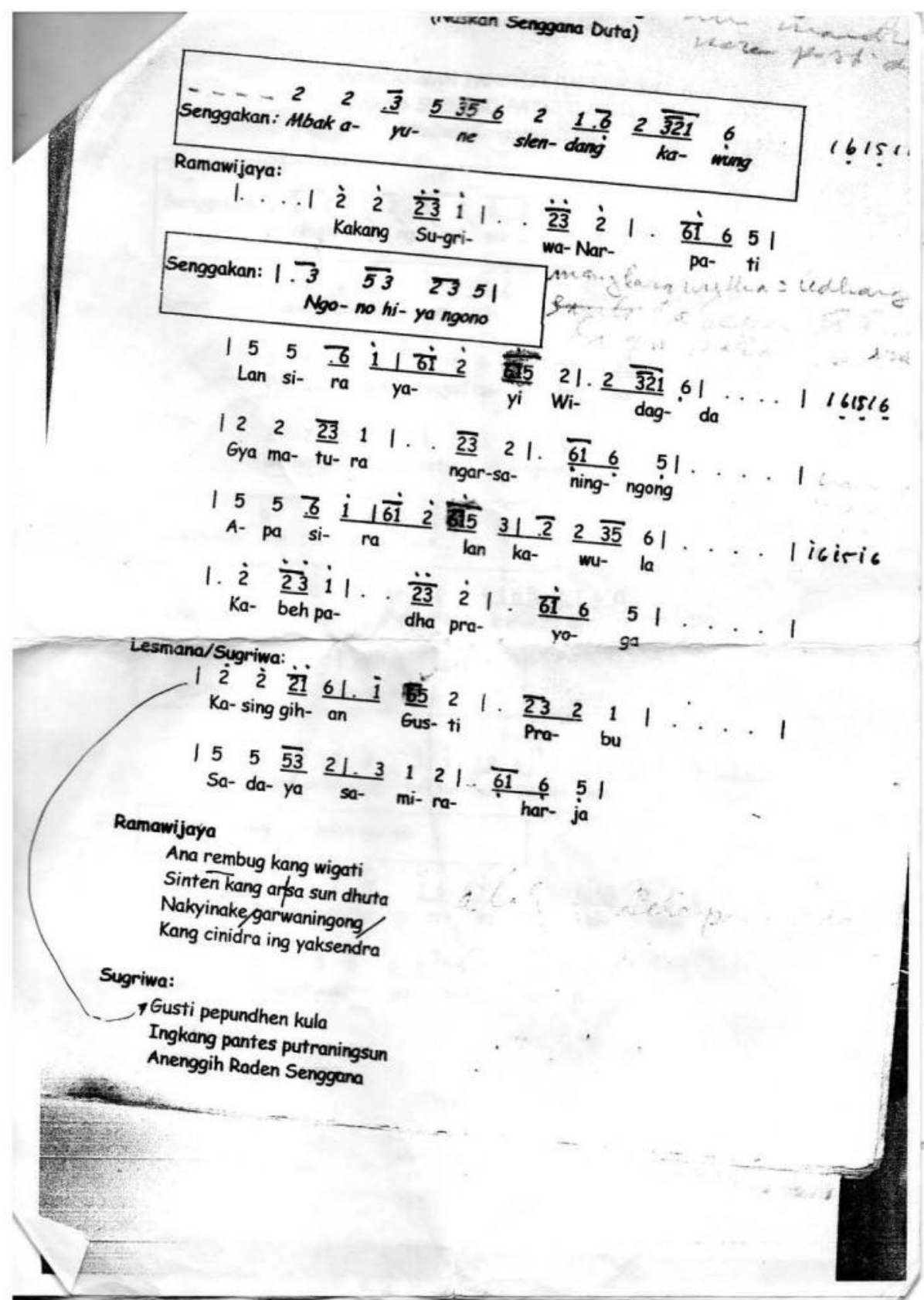

Gambar ILADRANG ASMARADANA KENYATINEMBE 
56 imasi, Vol. 16, No. 1, April 2018: 48 - 57

Gambar II Kinanthi

(Sumber: Naskeh pathet Sanga

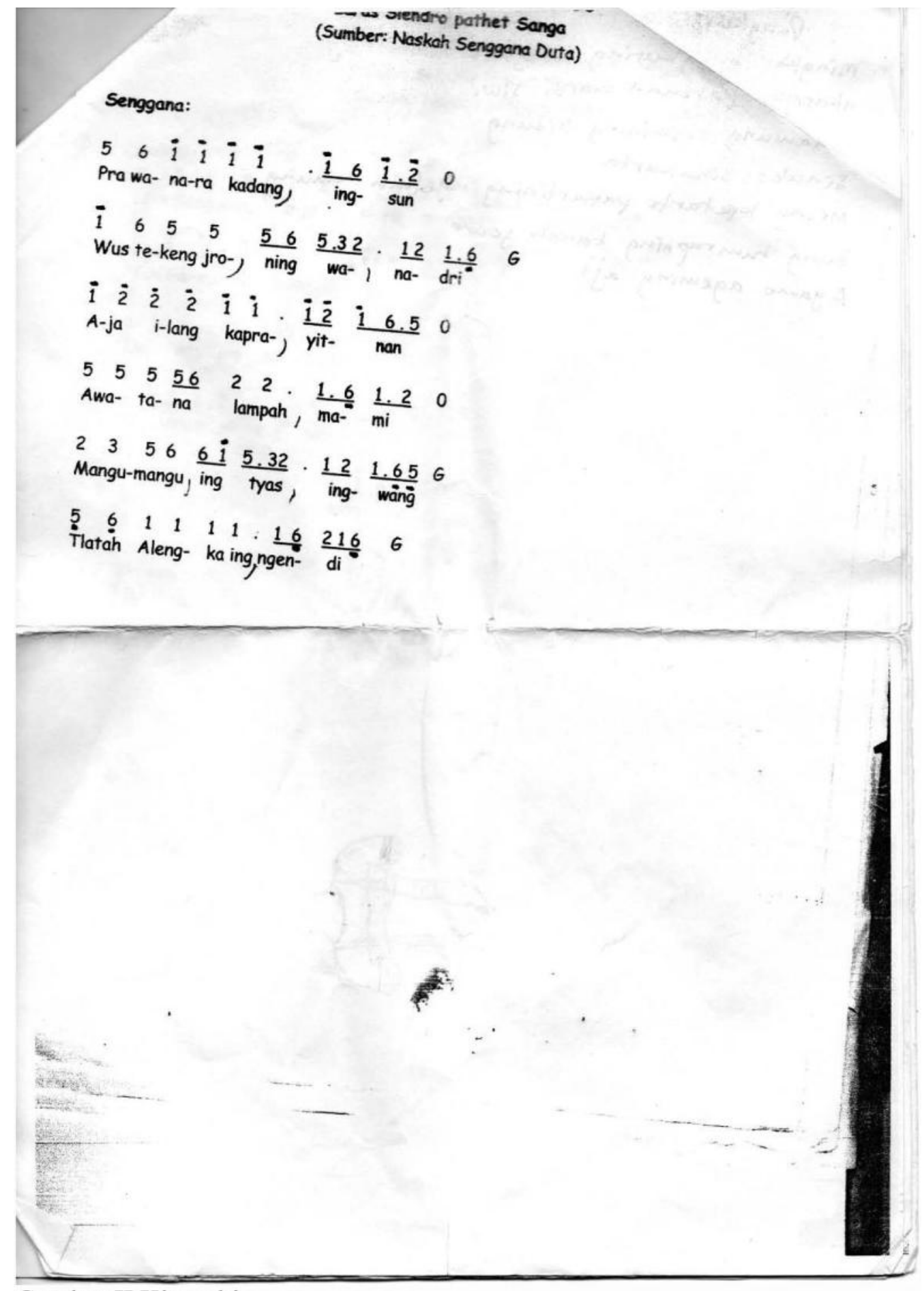

Gambar II Kinanthi 
Gambar III Rambangan Durma

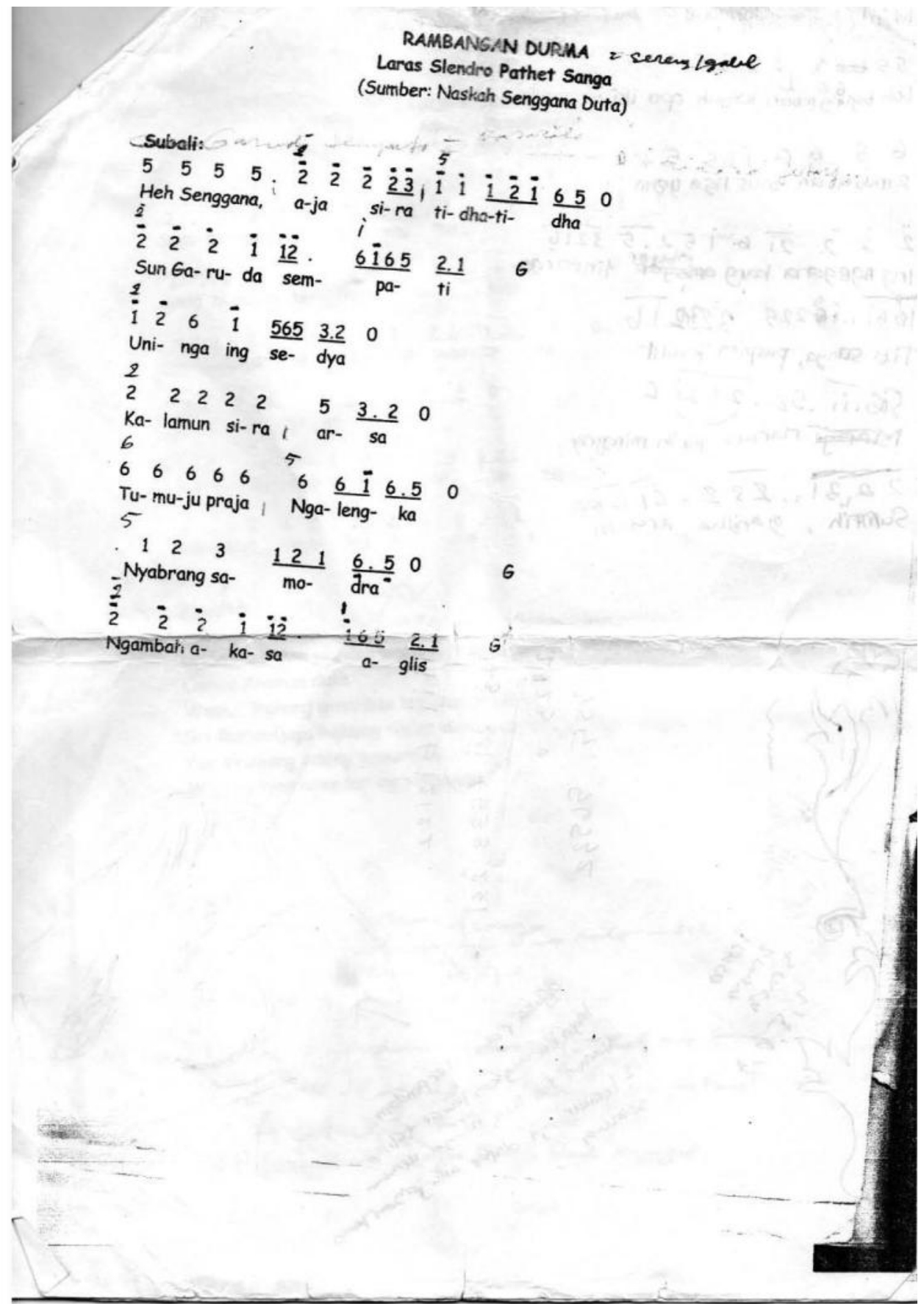

Gambar III Rambangan Durma 